\title{
Modeling cold supply chain environment of organized farm products retailing in India
}

\author{
Shashi Shashi ${ }^{\mathrm{a}^{*}}$ and Rajwinder Singh ${ }^{\mathrm{b}}$
}

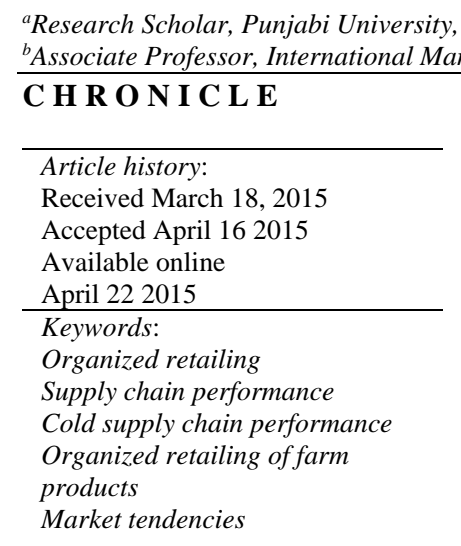

\section{Introduction}

The aim of a supply chain management (SCM) is to hold a cost-effective competitive advantage in the market by improving firms' overall SCP. It involves the combination of SC strategies, logistics, assets management, product life cycle management, procurement and SC planning. India stands at second spot in the globe in the production of farm products. However, at the same time, the consumption of farm products within the India is also very high (Viswanadham, 2005). Today, the business firms consider the world as a single marketplace and run their operations in overseas markets. This thinking leads to global competition and encourages firms to put their footprints in overseas markets. Hence, facing the high pressure of the global competition is a multifaceted challenge for firms. Therefore, firms are constantly doing research for finding new methods for improving their SCP. The SC management is a broader concept and the overall success or failure of the firm fully depends on SCP. Within the country, the post-harvest wastage percentage of produced farm products are very high due to poor SCP. Because of poor SCP, there is a badly need of proper and high quality of SCP to minimize these wastages and this will lead to cut down the overall cost, make final products more attractive, increase sales and high return. Here, the plan is to control the factors that affect farm products SCP (See Fig 1).

* Corresponding author Mob: 09876826051, 09882183161

E-mail address: shashikashav37@gmail.com (S. Shashi) 
During the past few years, there has been an increase trend on the income of middle class customers' demands for fresh and hygienic products for consumption. The term cold supply chain (CSC) is defined as a temperature-controlled SC. CSC enhances the shelf life of farm products by using temperature controlled facilities during warehousing and at the time of movement of farm products from one region to another (Zhang, 2007). The farm products are always sensitive in nature and a large share of farm products get wasted because of poor SCP (Montanari, 2008). Temperature monitoring (TM) is the main activity at the time of movement and storage of food products. The variety of farm products need temperature according to their sensitivity. The fruits and vegetables always get spoiled in high and low temperature, beside chilled products always need low temperature to maintain shelf life. Therefore, the continuous temperature monitoring is essential to reduce SC losses (Kuo \& Chen, 2010). Viswanadham (2005) also stress that temperature monitoring is necessary to enhance the shelf life of farm products. This chain is a key to fulfill the customer's expectations and to reduce post-harvest losses (Jackson et al., 2007) by pre-cooling facilities, cold storage, hygienic packaging, and proper warehousing. It also provides an edge to business house to provide off-season availability of farm products with preserved quality to build long term relationship with customers. The coordination between the SC partners is a very necessary to maintain an efficient firm. According to Hayat et al. (2012), SC coordination works as a vehicle between SC partners and enhances the firm CSCP. SC coordination aims at improving SCP by aligning the strategies and the goals of the business. In addition, it has an effect on firm's whole SCP (Cooper et al., 1997; Toni \& Tonachai, 2005; Giannakis \& Louis, 2011).

In this global market, a number of different market forces affect firm's SCP (Revilla \& Saenz, 2014). According to Singh et al. (2013) the OZR in India is in its growth stage. In spite of high growth rate of OZR in the country, many corporates are failed in tackling the pressure of high competitive global market and their business objectives due to their poor SCP. We have found that presently there is no specific standard model available for CSCP. So, we have recognized a strong need of a CSCP model for the upward mobility of this sector. Measuring SCP is the key complex managerial task with a variety of activities. For this study, we obtain variables by studying literature review that affects CSCP. The structural equation modeling (SEM) technique is used to develop and validate a confirmatory model for CSCP.

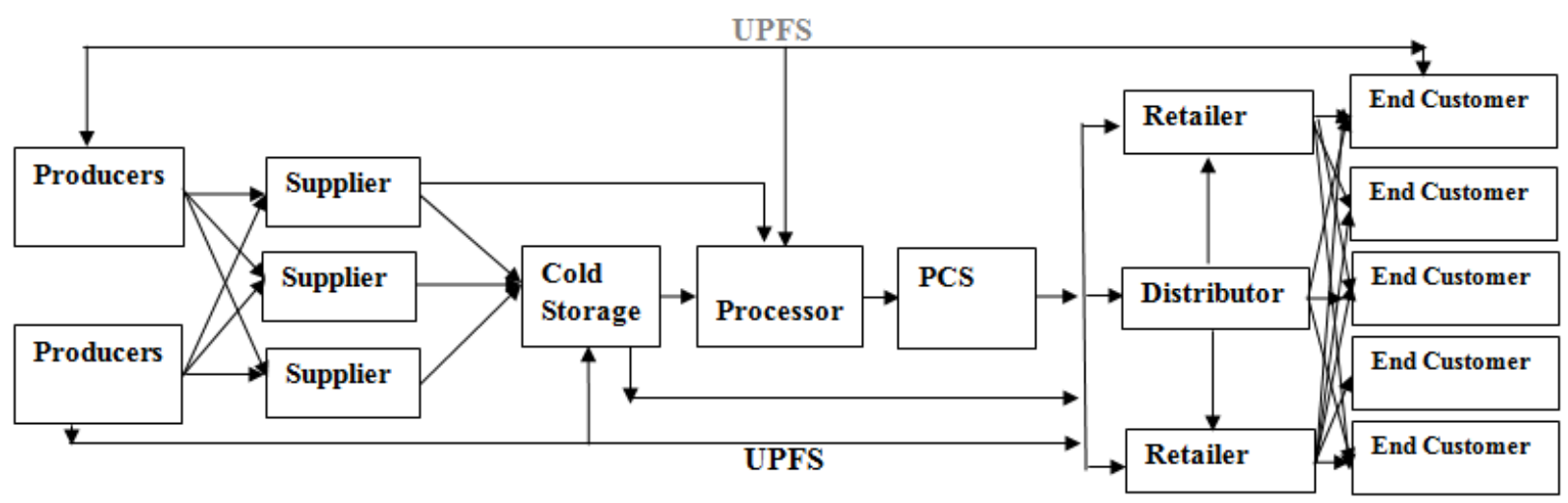

USPF $=$ Unprocessed Food Supply

$\mathrm{PCS}=$ Processor's Cold Storage

Transportation must be through cold chain vehicles

\section{Cold Supply Chain Process}

Fig. 2. The process of cold supply chain process 


\section{Factor affecting supply chain performance}

The SCP can be managed by effective planning, forecasting and control. Table 1 presents the list of variables used in this study for achieving the objectives of controlling the factors that affect CSCP in OFPR in India.

\subsection{Discussion}

Innovation is a prime factor to explore new commercial opportunities (Toni \& Tonachai., 2001; Srinivasan, et al., 2009; Rao \& Waghmare, 2014) in the market and is an emblem of future return. The principal aim of the innovation is to achieve a high level of cost efficiency. It is an application of fresh or modified knowledge for performance improvement (Weerawardena \& O'Cass, 2004).

\section{Table 1}

Factor affecting supply chain performance

\section{Performance affecting factors/Researchers}

Innovation: Kaplan and Nortan (1996), SSC (2000), Tan (2002), Chen and Qi (2003), Taylor (2004), Morgan (2004), Zeng and Lai (2008), Hansend et al. (2009), Srinivassan et al. (2009), Technopak (2010), BIS (2011), Gunday et al. (2011), Quesada (2012)

Shipping Errors: Harrison and New (2002), Morgan (2004), Viswanadham (2005), Zheng and Li (2008), Gruber and Panasiak (2011), Quesada (2012), Walsh (2014)

Process Quality: Luning et al. (2002), Saadany \& Jaber (2008), Bala (2013)

Strategic Purchasing: Pearson et al. (1996), Amelia at al. (1999), Chen \& Pulzar (2004); Garrett (2014), McMullen \& Adobar (2014)

Strategic Decision Making: Abele et al. (2004), Allen and Coates (2009), Teseng and Hung (2014)

Integration: Cooper (1993), HoulihanandHoulihan (1999), Danese et al. (2013)

Collaboration: Donlon (1996), Auramo et al. (2005), Agarwal and Shanker (2005), Kitchen and Hult (2007), KohandDemirbag (2007), Chuang et al. (2014)

Bullwhip Effect: Chen et al. (2000), Sun and Run (2005), Buchmeister (2008), Wang and He (2011) Francesco et al. (2013)

Temperate Monitoring: Gras (2006), Raab et al. (2011), Zeng et al. (2010), UkukuandSapers (2006), Anish and Aranb (2011) Raab et al. (2011)

Availability of Cold Chain Facilities: Viswanadham (2005), Jackson and Jevshink (2006), Montanari (2008), Kuoand Chen (2010), AnishandAran (2011), Fatehpuria (2013)

Product Life Cycle: Kotler(2005), Srinivasan et al. (2009), Chopra and Mendil (2010), Francesco et al. (2013)

Demand and Supply Management: Kotzab (2011), Mansuri et al. (2013),Wel et al. (2013), Ehrental et al. (2014), Patil and Divekar (2014)

Factory Location: $\quad$ Owen \& Daskin (1998), Bhatnager \& Sohal, (2005), Melo et al. (2009), Bogataj et al. (2011)

Inventory Handling Cost: Christopher (1998), TSO (2009)

Distribution Cost: Ellaram (1991), Saunders (1997), Tan et al. (2002), Talor (2004), Auramo et al. (2005), Singh et al. (2013)

Transportation: Sainathuni et al. (2010), Hasan and Alim (2010),Technopak (2010), Aung et al. (2012), Hazen and Byrd (2012), Quesada (2012), Fatehpuria (2013)

SC Relationships: Chen and Paulraj (2004), Tan et al. (2002), Miocevic et al. (2012), Quesada (2012)

Availability of Funds: Min \& Galle, (1997) Min \& Galle, (2001), Walker et al. (2008), Ageron et al. (2012)

Information Sharing: Donlon (1996), Alvarado and Kotzab (2001), Tan et al. (2002), Agarwal and Shanker (2005), Sakka and Genoulaz (2009), Kaya and Azaltun (2010), Technopak (2010), Pandey et al. (2010), Hazen and Byrd (2012), Anatan (2013)

Infrastructure: Abele et al. (2004), Copra (2010), Jacoby and Hodge (2008), Auramoet et al. (2005)

Performances Measurement: Berry et al. (1994), Lambert and Pohlen (2001), Lambert and Pohlen (2001), Sakka and Genoulaz (2009), Shen et al. (2013)

Information Technology: Ramdas and Speakman (2000), Sahin et al. (2000), Lambert and Terrance (2001), Mathis and Jackson (2007) Technopak (2010), Hasan and Alim (2010), Hall et al. (2012)

Risk Management: Blome and Schoenherr (2011), Sentia et al. (2013)

Lead time:Agarwal and Shanker (2005), Hasan and Alim (2010), Singh et al. (2013)

E-Supply: Lee et al. (2004), Liu et al. (2010)

Innovation is thus regarded as a crucial success factor in the Knowledge-Based Economy and it is linked with fostering the level of quality, productivity and designing etc. (Singh \& Rao, 2011; Tulsian 
\& Saini, 2014). Hansen et al. (2009) also highlighted that innovation is one of the most important variables that has an effect on SCP. According to Viswanadham (2005) the firms cannot run their operation without having the awareness of the legal and regulatory issues that has an impact on entire firm's SCP. The Government has pre-fixed the frontiers for doing business and firms have to do their business within these frontiers. The regulations like Ecological Act, Food Standards, Uniform commercial coding and Corporate Social Responsibility, Manufacturing and Labor Regulations, Safe and Efficient Transportation Act, Manufacturing and Transport Regulations affect SCP (Gong., 2008; Hales et al. 2009; Gruber \& Panasiak.,2010; Rao \& Patel, 2013).

In any type of SC, the factory location can be a crucial success or failure factor. The distance between the factory location and resource locations are two prime subject of concerns. As the distance between the resource location, factory location and market location increases the overall cost of business also increases. Similarly, many researchers believe that there was a close association between factory location and inadequate infrastructure. According Shankar (2014), new or well developed infrastructure helps the firms improve their SCP and well managed distribution activities. It minimizes lead time with prompt delivery between two channels. By this, the life of farm products is automatically increases. Abele et al. (2004) also indicates that the infrastructure is an important factor that affects SCP.

Most inventory systems do not consider time value effects. Firms need strategic purchasing (SP) to tackle business challenges. It is a proactive long-term business process that is related to purchasing activities of a company (Pearson et al., 1996; Melo et al., 2009). To purchase the required quality and quantity tools, machinery and raw material are the prime responsibility of the suppliers and they are entities as SC intermediaries. The demand and supply of the product or services always varies according to stage of product life cycle (PLC). In addition, different amount of investments and strategies are required according to the stage of the PLC. Srinivasan et al. (2009) reveal that the PLC is a key factor that affects CSCP. Hence, SP is a weapon to get a purchase required quality material at low price (Chen, 2004; McMullen \& Adobar, 2014). Furthermore, funds are very much essential from the initial stage of CSCP to run business operation. The firm cannot do anything in the absence of sufficient funds. For achieving this purpose, firm needs collaborative efforts. Fawcett et al. (2012) reveal that supply chain collaboration (SCC) is a dynamic competency in performing various tasks and (Kitchen \& Hult., 2007; Rexhausen et al., 2012; Wagner et al., 2012; He et al., 2013) creates effective paths to explore largely untouched potential opportunities within the market for increasing the commerce share of firms profitably. Singh et al. (2013) stressed that SCC plays a significant role in the business growth.

The management of demand \& supply is the biggest challenge. The uncertainty in demand and supply always invokes high risk. Fundamentally, it is a pre methodology for estimating that how much demand of product and services will occur in the future and how many resources will be sufficient for meeting these demands (Chen et al., 2004; Gong., 2008; Rao \& Patel, 2011; Makalef et al., 2013; Ehrental et al., 2014). Customer demand is the subject of variation, which is influenced by seasonal changes, price, product age, and availability, etc. During the flow, product personality is vital variables of superior SCP. This is based on color, volume, outer look and design of the material. These variable will help firm retain the customers for long time. In today's marketplace, a firm can reduce the risks of low sales, lost customers and low customer satisfaction (CS) by the balanced demand and supply management (DSM) and it creates wealth for the firm as well as worth for customers (Raturi \& Singhal., 1990; Shepherd \& Gunter., 2006; Singh et al., 2013; Patil \& Divekar, 2014).

Both the process quality and product quality are very essential to satisfy the customers. The exercise of proficient processing technologies shall facilitate to diminish the quantity of scrap and finally the product quality shall be superior. The use of statistical process control, root cause analysis of poor quality, improvement in process capability, staff training and development of facilities shall help to 
improve process quality. According to Saadany and Jaber (2008) and Bala (2013) process quality is an important factor for better SCP. The customer always expects prompt delivery of products and services. Lead time is the time between an order and delivery of goods or services and considers as a final decision making variable. Prompt delivery consequences helps in reducing handling cost, saving time, long-lasting purchasing and in building strong relationships with entire SC. Singh et al. (2013) identified lead time as a key indicator for measuring SCP.

Business integration permits producers to look into business processes across multiple suppliers. In this process, a number of SC members combine their operations, business functions and work together in achieving the prefixed goals. It delivers optimal situations for doing business on a large scale by assimilating the resources (Rao \& Padmanabhan, 2006; Zailani \& Rajagopal, 2005; Dodd \& Bouwer, 2014). Therefore in SC processes, misleading or variance in information from one end to another end is a major subject. Irregular or unbalanced coordination and communication is the main reason behind rising the Bullwhip effect (BE). The misleading or variance in information results excessive inventory investment, poor customer service and wastage of all firms' available resources (Lee et al., 1997; Patil et al., 2010; Hu et al., 2010; Feisel et al. 2011; Giannakis \& Louis., 2011). These errors are most common problem that is associated with delivery of products/services to the SC nodes. Many times short lead time, manual processing of outbound products and dispatch bottlenecks shall add to costly shipping errors, delivery related disputes, claims, and charge back. These shipping errors should be eliminated immediately, otherwise customer dissatisfaction shall not only lose the sale, but also discolor the company image. Many researchers (Farley, 1997; Patil et al., 2010; Wanger et al., 2012) identified it as an important key factor.

SC relationship is a widespread approach for handling a firm's interactions with the other parties which supply the products and services for users. In an ideal SC relationship, consumers and traders get connected in a way that permits them to interchange information, data and the visibility of status. Chen and Paulraj (2004) highlighted that the firm SC relationship is an indicator that affects SCP. Customer service (CS), service quality and customer loyalty have a considerable relationship with each other (Alonso et al., 2011; Shi et al., 2014). Customer feedback is an important tool to measure the CS (Chen et al., 2004; Richardson, 2005; Li et al., 2006; Rajaguru \& Matanda., 2013). It creates a loyal customer base for the business economy.

Typical information sharing (IS) environment comprises portfolio levels, manufacturing plans, demand forecasts and supply capability, and its paybacks are obtained by downstream and upstream suppliers. Advancement in information technology (IT) enables firms to rethink their SC strategies and explore new opportunities. In addition, it enables firms to drag their economy profit to the peak. But, at the same time, an incomplete or less IS and sick flow coordination hinders all these efforts (Beamon., 1999; Sahin \& Robinson, 2002; Singh, 2013; Rajaguru \& Matanda., 2013; Ing-Long et al., 2014). Both IS and information quality is influenced positively by trust in SC partners and shared vision between SC partners (Li \& Lin, 2006). According to Moberg et al. (2002) information sharing is the success factor in the system of each and every corporate SCM.

The performance of firms indicates its goodwill and effectiveness between competitors. The performance measurement (PM) is a key concern for future investments. It is a process of gathering, analyzing and designing a report to measure the accountability of the performance, profitability of individual customers, suppliers, distributor's logistics and organization (Chen, 2009; Cai et al., 2010; Singh et al., 2013,). Firms must move for measuring individual supplier's performance to manage their entire SCP.

Business processes includes variety of risks such as financial risk, sale losing risk, operational risk, technology risk, strategic risk and environmental risk etc. Risk management (RM) has become a prime concern for the firm, which is still further stressed by the current economic and political crisis (Thun \& Hoening, 2011; Bala, 2013). Hence, it is very much needed to evaluating the possibility of future 
losses and then to take most suitable steps to minimize these expected losses through effective RM planning (Feisel et al., 2011).

According to Piera et al. (2014), E-supply chain combination enables organizations in exchanging real time information, improve productivity, increase efficiency, and improve the ability of the SC to deliver faster and better products/services. It makes the balance between supply and demand, reduces costs by proper coordination and IS, and also reduces the threats of bullwhip effects by fast and direct communication. Averbakh and Baysan (2013) also found that E-supply had been one of the key variables that affect the internal business process. According to Wagner et al. (2012) strategic decision making (SDM) involves both the art of leadership and the science of management. SDM is the process of taking routine decision, regarding how to manage resources efficiently and to prepare the qualitative strategic plan for the future. Uru et al. (2011) also highlighted that the SDM has impact on business growth.

\section{Framework and gap analysis}

Knowledge of the business environment has always been a central issue for enterprises during SCP. This has been investigated through nodal measure such as requirement, expectation, capacity and path. SCM is not only making and delivering, but also is an intangible strategy to tackle the dense competitive arena. According to Farley (1997), SCM focuses on how firms use their supplier's processes, technology, capability to enhance competitive advantage, the coordination of the manufacturing, logistics and materials management functions within an organization. Here, the nodal points are (1) how to improve SC performance (2) How to gain competitive advantage? (3) How to reduce SC losses for better SCP (Chen et al., 2004 and Singh et al., 2013). Interruption and information gaps are the points that hinder agility of SCP. Hence, it's important to measure the factors and inter- dependency of constructs that affects CSCP.

This study is in the farm product context. OFPR industry is a high contributor to Indian GDP. India can also increase the total farm product export with controlling the percentage of post-harvest losses and maintaining proper balance in SC activities. Therefore, to find the appropriate solutions of poor SCP for upgrading the farm product SCP is a demand of time by developing and validating a proper CSCP model.

On the basis of literature review, it is clear that the trend of OZR in India is increasing day by day. In addition, it attracts many foreign OZR players for doing business in the Indian market because of enormous market opportunities. There has been extensive research related SCM. However, none of the previous studies focus on the CSCP. There have been some studies on Information Technology, Logistic aptitude and Integrated Logistics Support. But, these studies missed the structural relationships among the factors. Most of prior research discussed limited variables and there is absence of testing the construct correlation in these studies, also, till date there is no proper model for CSCP. In this study, an attempt has made to incorporate the relationships among various factors related to CSCP and we propose a confirmatory factor analysis model for better CSCP.

Within each system, the SCM includes all parts required for meeting and fulfilling the customer requirements. The SCM begins with the demand for product and services by the customers. The process firm buys the raw material from a variety of vendors, these vendors may buy the material from down layer suppliers. Packaging material for finished goods possibly will come from packaging companies, while packaging companies receive raw materials from other vendors to satisfy the needs of company customers. The major trouble in the farm supply is product's shelf life. The life of farm products gets started decreasing after harvesting and the probability of spoilage increases as, the length of the channel and delivery time get increased. The use of temperature machineries at the time of warehousing and transportation play a crucial role to minimize the amount of spoilage. The product should be delivered 
within minimum possible time from one end to another end. The next level of this SC is the merchandise store, where the end buyer visits or from where they get the products. A typical SCM may include a series of levels. These SC stages include: equipment and material vendors, manufacturers, wholesalers/distributors, retailers and buyers.

\section{Research design and methodology}

\subsection{Methodology}

The structured questionnaire has been used for achieving the research objectives. The 27 CSCP affecting variables and 7 points Likert scale have been used in this study. After the pre-pilot survey, Organizational Environment and HRM were excluded due to low Eigen and communality values. We removed the error of questionnaire on the basis of pre-pilot survey results and by consulting with SC experts. And, the most promising set of variables are selected for this research (Table 1).

\section{Table 2}

Scale statistics

\begin{tabular}{|c|c|c|c|c|c|}
\hline \multirow[t]{2}{*}{ SN } & \multirow[t]{2}{*}{ Items } & \multirow[t]{2}{*}{ Mean } & \multirow[t]{2}{*}{ Corrected Item total } & \multicolumn{2}{|c|}{ Communality } \\
\hline & & & & Initial & Final \\
\hline 1 & Transportation & 5.24 & .981 & 1.00 & .973 \\
\hline 2 & Demand \& Supply Management & 5.41 & .980 & 1.00 & .970 \\
\hline 3 & SC Relationships & 5.39 & .961 & 1.00 & .956 \\
\hline 4 & Inventory Handling Cost & 5.40 & .976 & 1.00 & .963 \\
\hline 5 & E-Supply & 5.25 & .935 & 1.00 & .904 \\
\hline 6 & Information Sharing & 5.43 & .919 & 1.00 & .869 \\
\hline 7 & Infrastructure & 5.28 & .937 & 1.00 & .905 \\
\hline 8 & Lead Time & 5.23 & .904 & 1.00 & .862 \\
\hline 9 & Strategic Decision Making & 5.41 & .971 & 1.00 & .956 \\
\hline 10 & Factory location & 5.37 & .980 & 1.00 & .979 \\
\hline 11 & Bullwhip Effect & 5.41 & .967 & 1.00 & .950 \\
\hline 12 & Performance Measurement & 5.41 & .937 & 1.00 & .905 \\
\hline 13 & Availability of funds & 5.28 & .902 & 1.00 & .854 \\
\hline 14 & Shipping Errors & 5.42 & .954 & 1.00 & .959 \\
\hline 15 & Information Technology & 5.40 & .955 & 1.00 & .931 \\
\hline 16 & Collaboration & 5.37 & .957 & 1.00 & .953 \\
\hline 17 & Innovation & 5.43 & .965 & 1.00 & .969 \\
\hline 18 & Risk Management & 5.40 & .947 & 1.00 & .921 \\
\hline 19 & Process Qulaity & 5.43 & .961 & 1.00 & .966 \\
\hline 20 & Distribution Cost & 5.26 & .948 & 1.00 & .924 \\
\hline 21 & PLC & 5.40 & .837 & 1.00 & .752 \\
\hline 22 & Availability of CC Facilities & 5.25 & .960 & 1.00 & .942 \\
\hline 23 & Integration & 5.37 & .965 & 1.00 & .961 \\
\hline 24 & Temperature Monitoring & 5.26 & .925 & 1.00 & .890 \\
\hline 25 & Strategical Purchasing & 5.41 & .974 & 1.00 & .961 \\
\hline
\end{tabular}

Statistic for Scale: $($ Mean=133.93; Variance $=67.250$, Std Dev. $=8.201, \mathrm{~N}$ of Variables $=25 ; \mathrm{N}$ of cases $=457$; alpha $=.885$ )

Finally, 25-item Likert scale survey has been used for collecting the data. In the final survey, the data were collected from 471 respondents, engaged in CSCP (Suppliers, processors, SC managers, agent, and distributors) within the region of Chandigarh, Punjab and Himachal Pradesh. Each respondent was asked to rate the each measurement variable in a 7 point Likert scale (1-Strongly disagree, 2-disagree, 3-somewhat disagree, 4- neutral, 5-strongly agree, 6- agree and 7-somewhat agree). But, we find 14 unengaged responses. Therefore we deleted 14 unengaged responses from our data set and finally, 457 responses were taken for this study. Further, the collected responses were analyzed by using SPSS principal component factor analysis method and scale reliability was done. 
According to Hair et al. (2009) the following level is required for conducting a research in business management:

- Cronbach alpha value $=>0.6$

- $\quad$ Item-to-total correlation $=>0.5$

- Inter- item- correlation $=>0.3$

The obtained values in this study are given below (Table 2):

- $\quad$ Cronbach Alpha value $=0.885$

- $\quad$ Item-to-total correlation $=>0.5$

- Inter- item- correlation $=>0.3$

Hence, the obtained results are sufficient for conducting a research. Here, the confirmatory modelling technique is used for developing a model for CSCP and we used AMOS 4.0 version to validate the model.

\section{Table 3}

Factor analysis results (A)

\begin{tabular}{|c|c|c|c|c|}
\hline \multirow[t]{2}{*}{ Variables } & \multicolumn{4}{|c|}{ Factors } \\
\hline & $\begin{array}{l}\text { Managerial } \\
\text { metrics (f1) }\end{array}$ & $\begin{array}{c}\text { Logistic Metrics } \\
\text { (f2) }\end{array}$ & $\begin{array}{c}\text { Relationship } \\
\text { metrics (f3) }\end{array}$ & $\begin{array}{l}\text { Innovation } \\
\text { metrics (f4) }\end{array}$ \\
\hline Demand \& Supply Management & .985 & & & \\
\hline Inventory Handling Cost & .981 & & & \\
\hline Strategical Purchasing & .980 & & & \\
\hline Strategic Decision Making & .977 & & & \\
\hline Bullwhip Effect & .974 & & & \\
\hline Information Technology & .965 & & & \\
\hline Risk Management & .959 & & & \\
\hline Performance Measurement & .951 & & & \\
\hline Information Sharing & .931 & & & \\
\hline PLC & .862 & & & \\
\hline Transportation & & .986 & & \\
\hline Availability of CC facilities & & .970 & & \\
\hline Distribution Cost & & .961 & & \\
\hline Infrastructure & & .951 & & \\
\hline E-supply & & .952 & & \\
\hline Temperature Monitoring & & .943 & & \\
\hline Lead Time & & .926 & & \\
\hline Availability of Funds & & .942 & & \\
\hline Factory Location & & & .988 & \\
\hline Integration & & & .980 & \\
\hline SC relationship & & & .977 & \\
\hline Collaboration & & & .974 & \\
\hline Innovation & & & & .984 \\
\hline Process Quality & & & & .982 \\
\hline Shipping Errors & & & & .979 \\
\hline$\%$ variance & 36.7 & 29.0 & 15.3 & 11.5 \\
\hline Cumulative \% variance & 36.7 & 65.7 & 81.1 & 92.696 \\
\hline Scale reliability alpha & .989 & .985 & .987 & .982 \\
\hline
\end{tabular}

$\mathrm{KMO}=.888$, Bartlett's Test of Sphericity (Chi-Square $=8994.985$, Df. $=300$, Sig. $=0.00$

\subsection{Factor analysis results}

The scale mean for twenty five key variables is 133.93 (Table 2).

If all the variables are rated at $7=25 * 7=175$ 
Total percentage of explained construct $=$ scale mean $/$ rated variables $* 100$

$$
\begin{aligned}
& \text { Percentage }=133.93 / 175 * 100 \\
& \text { Percentage }=76.53
\end{aligned}
$$

Here, $76.53 \%$ of constructs is explained. This is sufficient to explain construct validity. The factor analysis taxonomy and results are shown in the Table 3 (A) \& Table 4 (B). The correlation is shown in Table 5. Here, all the requirements of performing factor analysis are fulfilled. The principal component method is used for this analysis.

Table 4(B)

\begin{tabular}{|c|c|c|c|c|c|c|}
\hline Factor & $\begin{array}{l}\text { Total } \\
\text { covered } \\
\text { variables }\end{array}$ & $\begin{array}{l}\text { Factor loading } \\
\text { range }\end{array}$ & $\begin{array}{l}\text { Inter-item- } \\
\text { correlation range }\end{array}$ & $\begin{array}{l}\text { Item-to-total } \\
\text { correlation } \\
\text { range }\end{array}$ & $\begin{array}{l}\text { Explained } \\
\text { variance \% }\end{array}$ & Eigen value \\
\hline Managerial Metrics & 10 & 0.985 to 0.862 & 0.989 to 0.754 & 0.980 to 0.837 & 36.780 & 9.195 \\
\hline Logistic Metrics & 8 & 0.986 to 0.924 & 0.966 to 0.809 & 0.981 to 0.902 & 29.016 & 7.254 \\
\hline Relationship Metrics & 4 & 0.972 to 0.931 & 1.000 to 0.546 & 0.980 to 0.965 & 15.307 & 3.827 \\
\hline Innovation Metrics & 3 & 0.984 to 0.977 & 0.955 to 0.940 & 0.965 to 0.654 & 11.593 & 2.898 \\
\hline
\end{tabular}

The results of factor analysis

- $\quad$ Scale reliability $=0.885$

- $\quad$ Bartlett's test of Sphericity has chi. Square $=8994.985$

- $\quad$ Kaiser-Meyer-Olkin Measure of the sampling adequacy $=0.888$

- $\quad$ Degree of freedom $=300$

- $\quad$ Level of significance $=0.00$

- $\quad$ The communality large range from 0.979 to 0.752

\subsection{Findings}

The 25 variables has been used to measure the CSCP of OFPR and they have been classified into four groups. The first most important group of the key variables is a managerial metric with ten most important variables. The second important key indicator group is logistic metrics that consist of eight key variables. The third group of the key variables is relationship metrics that consists of four key performance variables. And, fourth and last group is innovation metrics, which consists of three key performance variables. The results of these groups are shown in Table 3 (A) \& Table 4 (B). These groups shall be helpful for developing better strategies and to make changes in existing strategies in this industry.

\section{Table 5}

\begin{tabular}{|c|c|c|c|c|c|c|c|c|}
\hline & $\begin{array}{l}\text { Demand } \\
\text { \&SCM }\end{array}$ & Transportation & Factory Location & Innovation & Summated 1 & Summated 2 & Summated 3 & Summated 4 \\
\hline $\begin{array}{l}\text { Demand } \\
\text { \&SCM }\end{array}$ & 1 & -.005 & .057 & -.004 & $.977^{* *}$ & -.018 & .057 & -.002 \\
\hline Transportation & -.005 & 1 & -.021 & -.017 & .009 & $.985^{* *}$ & -.020 & -.023 \\
\hline $\begin{array}{l}\text { Factory } \\
\text { Location }\end{array}$ & .057 & -.021 & 1 & -.016 & .059 & -.037 & $.989^{* *}$ & -.026 \\
\hline Innovation & -.004 & -.017 & -.016 & 1 & -.005 & -.014 & .002 & $.985^{* *}$ \\
\hline Summated 1 & $.977^{* *}$ & .009 & .059 & -.005 & 1 & -.009 & .057 & -.005 \\
\hline Summated 2 & -.018 & $.985^{* *}$ & -.037 & -.014 & -.009 & 1 & -.035 & -.022 \\
\hline Summated 3 & .057 & -.020 & $.989^{* *}$ & .002 & .057 & -.035 & 1 & -.009 \\
\hline Summated 4 & -.002 & -.023 & -.026 & $.985^{* *}$ & -.005 & -.022 & -.009 & 1 \\
\hline
\end{tabular}

Correlation

**. Correlation is significant at the 0.01 level (2-tailed).

\subsection{Structural model results}

The proposed SEM is shown in Fig. 2. It has Chi-square $=256.763$, Degrees of freedom $=269$, and Probability level $=0.000$. The fit measure are; RMR $=0.009, \mathrm{NFI}=0.897, \mathrm{IFI}=0.918, \mathrm{TLI}=0.908$ and CFI $=0.918$. Here, the correlation of factor analysis is not significant. So, all the factors are 
independent factors, because of their correlation value less than 0.05. In this model error loading is positive. Hence, this is a valid model.

\subsection{Effect for Metric}

In this study, managerial metric spans over variety of nodal managerial activities. The followings are the total effects for this metric (Fig.2): demand and supply management (1.00), inventory handling cost (0.98), PLC (0.92), strategic purchasing (.96), bullwhip effect (.94), information technology (0.91), bullwhip effect (0.94), performance measurement (0.93), risk management (0.95), information sharing (0.96) and strategic decision making (0.99). From these, it is revealed that strategic decision making, bullwhip effect and DSM play significant role in the CSCP. At the same time, the SC of farm products always wears high probability of loss. So, the strategic decision and purchasing should be according to the requirement and the timely exchange of data and information among the SC intermediates for the measurement of uncertainty. Here, the main focus should be that the firms will have to enhance the professionalism in the SC for accomplishing the objective of compatible SCP.

Fig. 2 presents the total effects for logistic metric: transportation (.93), availability of CC facilities (0.99), distribution cost (0.98), infrastructure (0.97), E-supply (0.96), temperature monitoring (1.00), lead time (0.95) and availability of funds (0.94). In today's globalized world, efficient logistics management is even more important to ensure efficiency in production and distribution. In this factor, transportation, availability of funds and temperature monitoring plays a vital role. This metric has serious repercussion on distribution and coverage of business operations. Appropriate distribution and adequate infrastructure help in increasing the total share of profit. The customer satisfaction can be fulfilled by providing fresh products through reducing lead time and E-supply. Here, the key point is that the growth rate of market share leverages and invokes by the initial screening of necessities and strategic logistic contribution. Hence, absolute or proper implications of this metric will help the corporate to enhance the SC capabilities in the area of SCP.

The following are the total effects of relationship metric (Fig.2): factory location (1.00), integration (0.99), SC relationship (0.95) and collaboration (0.96). In this metric, factory location plays a major role and it is followed by integration and collaboration. In the business, the healthy relationships are considered as a critical success factors for the long-lasting survival of the firm in this competitive world with high commitments. But, here the question arises that how much healthy relationships the firms has established with their SC player and customers? The healthy and cooperative relations among the SC players provide supremacy to firm to cope the competition more effectively. The work finds that the relationship metric is canalizing subject in nature and its variables are complementary to each other. Thus, it mitigates the probability of uncertain jeopardy.

The following are the total effects for innovation metric (Fig.2): The total effect for are: innovation (1.00), process quality (0.98) and shipping errors (0.97). In this factor, the innovation is a leading variables and plays very crucial role followed by quality and shipping errors. Innovation is an emblem of commercial growth and hence, traders need to maintain the continuous focus on innovation for accomplishing the purpose of enhancement of business scope and business areas. Here, it is important to mention that the less shipping error leads to foster the level of internal inputs and processes and firms have to adhere to the govt. rules and regulations. All the variables here is matched with study allocated in Table 1. 


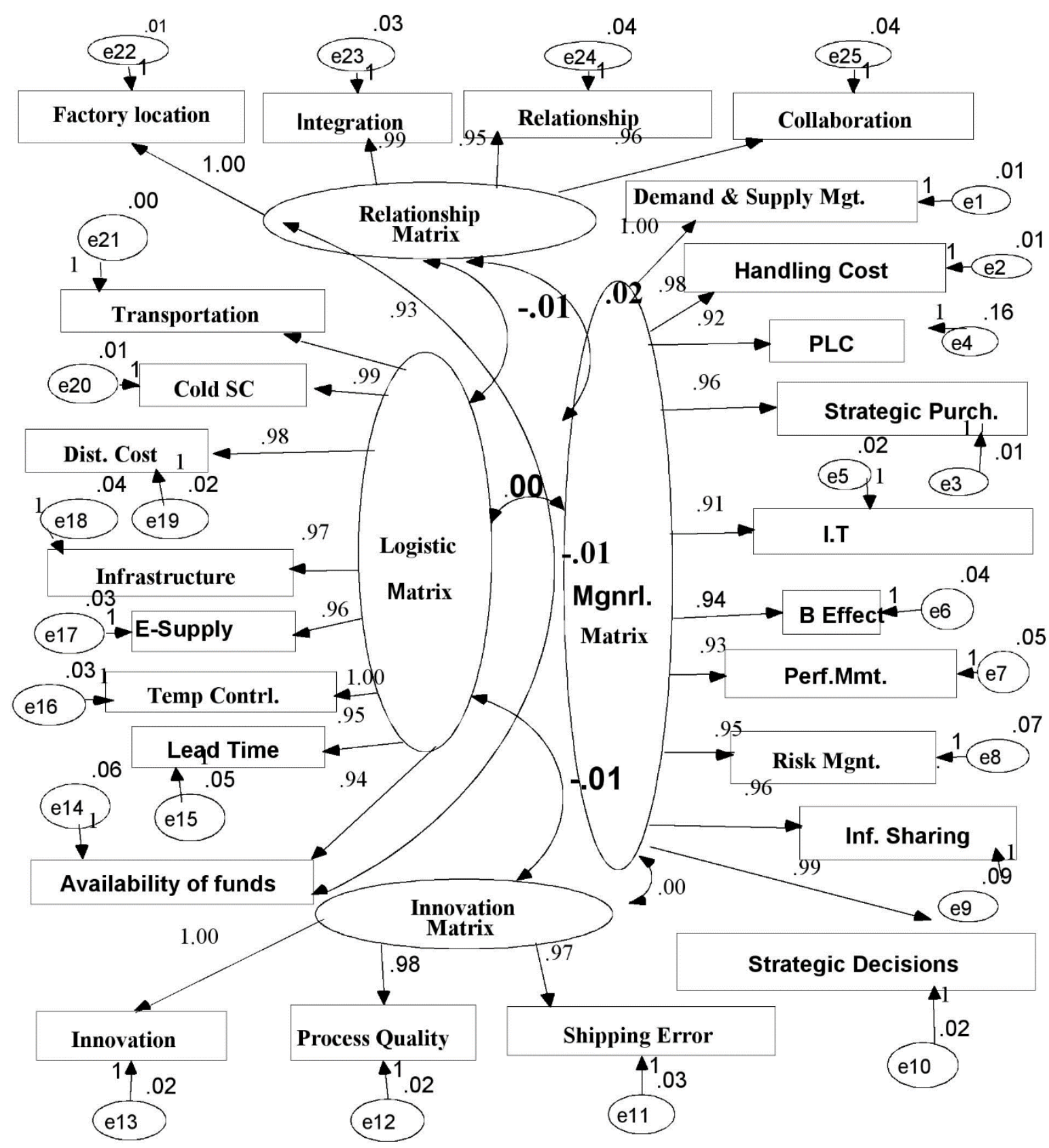

Fig. 2. Confirmatory model

\subsection{Model validity results and discussion}

According to McDonald and Ho, (2002) define as an absolute fit model as a degree of model fitness that how well a model fits the collected sample data. In this study, the AMOS 4.0 version is used to test the model (Fig. 2). In, the pilot survey data are collected from the 200 respondents and confirmatory model was developed. And this final survey is conducted and data is collected from the rest of 257 respondent and then the model was developed. Both the models have almost the same results. Hair et al. (2010) suggested the criteria of goodness-of-fit model. They suggested that Probability level should be less than 0.05 , RMR range should be between 0 to 1 , NFI range between 0 to 1 , TLI value should fall below 0 or above 1 and CFI value should be between 0 and 1 . In this model, the obtained results are given below:

- $\quad$ Chi-square $=256.763$ 
- Degrees of freedom $=269$

- $\quad$ Probability level $=0.00$

- $\quad$ RMR value $=0.009$

- $\quad$ NFI range $=0.908$

- $\mathrm{TLI}=0.908$

- $\quad$ CFI value $=0.918$.

Hence, the model is overall fit.

\section{Conclusion}

The developed model for CSCP has been summarized in the Fig. 2 and the results of this model have been empirically tested and validated. All the 25 variables are well arranged to meet the SCP measurement requirements. SCP measurement is a complex and span activity that has an effect on SC practices. Firms need a structured method to examine existing performance measurement system (Medori et al., 2009) to come out of fuzzy commerce situations. In this highly competitive arena, the high and deep level, managerial inputs is required in order to calibrate and strengthen SC performance. A firm should realize that its individual efficiency and competitiveness depends heavily on strengthening its SC relationship with its business partners. In order to uphold the maximum probable SCP readiness, it is necessary to get better logistic capacities for CSCP effectively. Logistics must work out a guiding role in representative resourceful visualization and programs to apex management. SCP cannot be enhanced by controlling a single factor. The proper management of variance in SC structure is essential for implementing this metric as a strategic tool in SC and immediate elimination of shipping errors. Information sharing is a weapon that's as power of leading the business even in complexities; hence, firms have to work in a unified manner in order to take the benefits of business opportunities.

Innovation and infrastructure are the area, where more investment is required to uplift the standard of SCP. The investigation also explores, a number of small uneducated village farmers wind up or decreased their capacity of production because of post-harvest losses and hard government policies. Well managing inventories requires appropriate route, manpower and technology. Therefore, the horticultural authorities and agricultural authorities should take more initiatives to accumulate these farmers' subsidies, group solar cold storage and regular motivational \& awareness programs. Authorities should help producers, in setting up their production targets and supply of farm products in the market. By this, the contribution of the farm products in GDP can be maximized.

The outcomes of this investigation are anticipated to be used as guidance for the betterment of CSCP. In addition, the proposed model can be extended to provide the management index for farm companies which cover various products and materials.

\section{Research limitation/future research}

Despite the absolute model fit, this research has one main limitation: the interaction with top management was limited during final survey. The contacts with top management are always necessary for deep exploration of any sector. Also, there is a robust need to work on all the categories of agroproducts for the boosting the all over return and for preparing better plans for of agriculture industry.

\section{References}

Abele, S., Bless, H., \& Ehrhart, K. M. (2004). Social information processing in strategic decisionmaking: why timing matters. Organizational Behavior and Human Decision Processes, 93(1), 2846. 
Adobor, H. \& McMullen, R.S. (2014) Strategic purchasing and supplier partnerships-The role of a third party organization. Journal of Purchasing and Supply Management, 20 (4), 263-272.

Ageron, B., Gunasekaran, A. \& Spalanzani, A. (2012). Sustainable supply management: An empirical study. International Journal of Production Economics, 140 (1), 168-182.

Alonso, A.D. (2011). Muscadines, wineries and value-added products: an exploratory study. British Food Journal, 113 (3), 322-337.

Averbakh, I. \& Baysan, M. (2013) Approximation algorithm for the on-line multi-customer two-level supply chain scheduling problem, Operations Research Letters, 41(6), 710-714.

Bala, H. (2013). The effects of IT-enabled supply chain process change on job and process outcomes: A longitudinal investigation. Journal of Operations Management, 31 (6), 450-473.

Beamon, B.M. (1999). Designing the green supply chain. Logistics Information Management, 12 (4), 332-342.

Bhatnagar, R. \& Sohal, A.S. (2005). Supply chain competitiveness: measuring the impact of location factors, uncertainty and manufacturing practices. Technovation, 25 (5), 443-456.

Blome, C., \& Schoenherr, T. (2011). Supply chain risk management in financial crises-A multiple case-study approach. International journal of production economics, 134(1), 43-57.

Cai, S., Yang, Z. \& Hu, Z. (2010) The effects of volume consolidation on buyer-supplier relationships: A study of Chinese firms. Journal of Purchasing and Supply Management, 16(3), 152-162.

Chen, I.J. \& Paulraj, A. (2004). Towards a theory of supply chain management: the constructs and measurements. Journal of Operations Management, 22, 119-150.

Chen, I.J., Paulraj, A. \& Lado, A.A. (2004). Strategic purchasing, supply management, and firm performance. Journal of Operations Management, 22 (5), 505-523.

Dodd, M.C. \& Bouwer, J.J. (2014). The supply value chain of fresh produce from field to home: refrigeration and other supporting technologies. In Postharvest Handling, ${ }^{\text {rd }}$ EDT., Academic Press, San Diego, 2014, Chapter 16, pp. 449-483.

Ehrenthal, J. C. F., Honhon, D. B. L. P., \& Van Woensel, T. (2014). Demand seasonality in retail inventory management. European Journal of Operational Research, 238(2), 527-539.

Farley, G. A. (1997). Discovering Supply chain management: A roundtable discussion. American Production and Inventory Control Society-The Performance Advantag, 7(1), pp. 38-39.

Fawcett, S. E., Fawcett, A. M., Watson, B. J., \& Magnan, G. M. (2012). Peeking inside the black box: toward an understanding of supply chain collaboration dynamics. Journal of Supply Chain Management, 48(1), 44-72.

Feisel, E., Hartmann, E. \& Giunipero, L. (2011). The importance of the human aspect in the supply function: Strategies for developing PSM proficiency. Journal of Purchasing and Supply Management, 17(1), 54-67.

Giannakis, M. \& Louis, M. (2011). A multi-agent based framework for supply chain risk management. Journal of Purchasing and Supply Management, 17 (1), 23-31.

Gong, Z. (2008). An economic evaluation model of supply chain flexibility. European Journal of Operational Research, 184(2), 745-758.

Gruber, J., \& Panasiak, D. (2011). Regulation and non-regulatory guidance in Australia and New Zealand with implications for food factory design. Hygienic Design of Food Factories, A volume in Woodhead Publishing Series in Food Science, Technology and Nutrition, 564 (4), 115142.

Hair, J. F., Black, W. C., Babin, B. J., Anderson, R. E., \& Tatham, R. L. (2006). Multivariate data analysis (Vol. 6). Upper Saddle River, NJ: Pearson Prentice Hall.

Hales, D.N., Chakravorty, S.S. \& Sridharan, V. (2009). Testing Benford's Law for improving supply chain decision-making: A field experiment. International Journal of Production Economics, 122 (2), 606-618.

Hansen, E. G., Grosse-Dunker, F., \& Reichwald, R. (2009). Sustainability innovation cube-a framework to evaluate sustainability-oriented innovations.International Journal of Innovation Management, 13(04), 683-713. 
Hansen, G. S., \& Wernerfelt, B. (1989). Determinants of firm performance: The relative importance of economic and organizational factors. Strategic management journal, 10(5), 399-411.

He, Z., Wang, S. \& Cheng, T.C.E. (2013). Competition and evolution in multi-product supply chains: An agent-based retailer model. International Journal of Production Economics, 146 (1), 325-336.

Hu, S., Ye, Q., Chi, W. \& Flynn, B.B. (2010). Supply chain structure, inventory turnover, and financial performance: Evidence from manufacturing companies in China. Available at SSRN: http://ssrn.com/abstract=1670261 or http://dx.doi.org/10.2139/ssrn.1670261.

Jackson, V., Blair, I. S., McDowell, D. A., Kennedy, J., \& Bolton, D. J. (2007). The incidence of significant foodborne pathogens in domestic refrigerators. Food control, 18(4), 346-351.

Ketchen, D. J., \& Hult, G. T. M. (2007). Bridging organization theory and supply chain management: The case of best value supply chains. Journal of Operations Management, 25(2), 573-580.

Kotler, P., \& Keller, K. (2011). Marketing Management. Pearson Education, Prentice Hall.

Kuo, J. C., \& Chen, M. C. (2010). Developing an advanced multi-temperature joint distribution system for the food cold chain. Food Control, 21(4), 559-566.

Lambert, D.M., \& Pohlen, T.L. (2001). Supply Chain Metrics. The International Journal of Logistics Management, 12 (1), 1-19.

Lavastre, O. \& Gunasekaran, A. (2012.) Alain Spalanzani, Supply chain risk management in French companies. Decision Support Systems, 52 (4), 828-838.

Lee, H.L., Padmanabhan, V., Wang, S., 1997. The bullwhip effect in supply chains. MIT Sloan Management Review, spring, 38(3), 93-102.

Li, S., \& Lin, B. (2006). Accessing information sharing and information quality in supply chain management. Decision support systems, 42(3), 1641-1656.

Liu, H., Ke, W., Wei, K. K., Gu, J., \& Chen, H. (2010). The role of institutional pressures and organizational culture in the firm's intention to adopt internet-enabled supply chain management systems. Journal of Operations Management, 28(5), 372-384.

Markgraf, B. (2014). Demand Media, "Integrating business processes for global alignment \& supply chain management Retrieved from: <http://smallbusiness.chron.com/integrating-businessprocesses-global-alignment-supply-chain-management-73032.html>, Available at: 29 March, 2014.

Mathis, R. L., Jackson, J. H. (2007). Human Resource Management, South-Western College Pub.

McDonald, R. P., \& Ho, M. H. R. (2002). Principles and practice in reporting structural equation analyses. Psychological methods, 7(1), 64.

Melo, M.T., Nickel, S.,Saldanha-da-Gama, F. (2009). Facility location and supply chain management

- A review. European Journal of Operational Research, 196 (2), 401-412.

Moberg, C. R., Cutler, B. D., Gross, A., \& Speh, T. W. (2002). Identifying antecedents of information exchange within supply chains. International Journal of Physical Distribution \& Logistics Management, 32(9), 755-770.

Montanari, R. (2008). Cold chain tracking: a managerial perspective. Trends in Food Science \& Technology, 19(8), 425-431.

Owen, S.H. \& Daskin, M.S. (1998). Strategic facility location: A review. European Journal of Operational Research, 111, 423-447.

Patil, H., \& Divekar, R.B. (2014). Inventory management challenges for B2C e-commerce retailers. Procedia Economics and Finance, 11, 561-571.

Patil, R., Avittathur, B. \& Shah, J. (2010). Supply chain strategies based on recourse model for very short life cycle products. International Journal of Production Economics, 128 (1), 3-10.

Pawar, P. J., Rao, R. V., \& Davim, J. P. (2010). Multiobjective optimization of grinding process parameters using particle swarm optimization algorithm. Materials and Manufacturing Processes, 25(6), 424-431.

Pearson, J. N., Ellram, L. M., \& Carter, C. R. (1996). Status and recognition of the purchasing function in the electronics industry. International Journal of Purchasing and Materials Management, 32(1), 30-36.

Piera, C., Roberto, C., Giuseppe, C. \& Teresa, M. (2014). E-procurement and E-supply Chain: Features and Development of E-collaboration, IERI Procedia, 6, 8-14. 
Rajaguru, R. \& Matanda, M.J. (2013). Effects of inter-organizational compatibility on supply chain capabilities: Exploring the mediating role of inter-organizational information systems (IOIS) integration. Industrial Marketing Management, 42 (4), 620-632.

Rao, R. V., \& Padmanabhan, K. K. (2006). Selection, identification and comparison of industrial robots using digraph and matrix methods. Robotics and Computer-Integrated Manufacturing, 22(4), 373383.

Rao, R.V, \& Patel, B.K. (2011). Novel method for decision making in manufacturing environment. Journal of Engineering and Manufacturing, 225(3), 422-434.

Rao, R., \& Patel, V. (2013). Comparative performance of an elitist teaching-learning-based optimization algorithm for solving unconstrained optimization problems. International Journal of Industrial Engineering Computations, 4(1), 29-50.

Rao, R. V., \& Waghmare, G. G. (2014). A comparative study of a teaching-learning-based optimization algorithm on multi-objective unconstrained and constrained functions. Journal of King Saud University-Computer and Information Sciences, 26(3), 332-346.

Rexhausen, D., Pibernik, R. \& Kaiser, G. (2012). Customer-facing supply chain practices-The impact of demand and distribution management on supply chain success. Journal of Operations Management, 30 (4), 269-281.

Revilla, E., \& Sáenz, M. J. (2014). Supply chain disruption management: Global convergence vs national specificity. Journal of Business Research, 67(6), 1123-1135.

Richardson, H. L. (2005). How do you know your supply chain works?. Logistics Today, 46(6).

Saadany, A.M.A.E. \& Jaber, M.J. (2008). Coordinating a two-level supply chain with production interruptions to restore process quality. Computers \& Industrial Engineering, 54(1), 95-109.

Sahin, F., \& Robinson, E. P. (2002). Flow coordination and information sharing in supply chains: review, implications, and directions for future research. Decision sciences, 33(4), 505-536.

Shi, Y., Prentice, C., \& He, W. (2014). Linking service quality, customer satisfaction and loyalty in casinos, does membership matter?. International Journal of Hospitality Management, 40, 81-91.

Sims, D. (2013). Integrated supply chains maximize efficiencies and savings. Retrieved from $<$ http://news.thomasnet.com/IMT/2013/07/23/integrated-supply-chains-maximize-efficienciesand-savings/> Accessed on 12 April 2014.

Singh, D., \& Rao, R. (2011). A hybrid multiple attribute decision making method for solving problems of industrial environment. International Journal of Industrial Engineering Computations, 2(3), 631644.

Singh, R. (2013). Practices to Compete Supply Chain Performance of Organized Garment Retailing. International Review of Social Sciences \& Humanities, 5(2).

Singh, R., Sandhu, H. S., Metri, B. A., \& Kaur, R. (2013). Modeling Supply Chain Performance: A Structural Equation Approach. International Journal of Information Systems and Supply Chain Management (IJISSCM), 6(4), 18-41.

Singh, R., Sandhu, H. S., Metri, B. A., \& Singh, M. P. (2003). Modeling Supply Chain Performance of Organized Garment Retailing. International Journal of Scientific and Research Publications, 3(3), $1-10$.

Srinivasan, S., Pauwels, K., Silva-Risso, J., \& Hanssens, D. M. (2009). Product innovations, advertising, and stock returns. Journal of Marketing, 73(1), 24-43.

Thun, J.H. \& Hoenig, D.(2011) An empirical analysis of supply chain risk management in the German automotive industry. International Journal of Production Economics, 131(1), 242-249.

Toni, A.D. \& Tonchia, S. (2001) Performance measurement systems - Models, characteristics and measures. International Journal of Operations \& Production Management, 21 (1/2), 46 - 71.

Tulsian, M., \& Saini, N. (2014). Market-driven innovations in rural marketing in India. International Journal of Scientific \& Engineering Research, 5 (5), 1439-45.

Uru, F.O., Calıskan, S.C., Atan, O. \& Aksu,M. (2011) How Much Entrepreneurial Characteristics Matter in Strategic Decision-Making?, Procedia - Social and Behavioral Sciences, 24, 538-562. 
Viswanadham, N. (2005). Cold Chain management: India-Singapore initiative. The Institute for South Asian Studies, National University of Singapore, Singapore.

Wagner, S.M., Grosse-Ruyken, P.T. \& Erhun, F. (2012). The link between supply chain fit and financial performance of the firm. Journal of Operations Management, 30(4), 340-353.

Weerawardena, J., \& O'Cass, A. (2004). Exploring the characteristics of the market-driven firms and antecedents to sustained competitive advantage. Industrial Marketing Management, 33(5), 419-428.

Zailani, S., \& Rajagopal, P. (2005). Supply chain integration and performance: US versus East Asian companies. Supply Chain Management: An International Journal, 10(5), 379-393.

Zheng, S. \& David, C. M. (2000). The new spectrum of the cross enterprise solution: the integration of Supply chain management and enterprise resource planning systems. Journal of Computer Information Systems, 41(2), 84-93. 